\title{
Drivers of illegal livelihoods in remote transboundary regions: the case of the Trans-Fly region of Papua New Guinea
}

\author{
Sara Busilacchi $^{1}$, James R. A. Butler ${ }^{1}$, Wayne A. Rochester ${ }^{2}$ and Joseph Posu ${ }^{3}$
}

\begin{abstract}
Remote transboundary regions in developing countries often contain abundant natural resources. Many of these resources are being overexploited to supply an ever-increasing demand from Asia, often via illegal cross-border trade. Understanding the systemic issues that drive households to engage in illegal activities in transboundary regions is a prerequisite for designing effective interventions and diverting livelihoods toward sustainable trajectories, but is rarely applied. This study analyzed the drivers of illegal trade in marine products, e.g. sea cucumber, shark fin, and fish bladders, among coastal villages in Papua New Guinea that border Indonesia and Australia in the Trans-Fly region. Mixed-methods (household questionnaire surveys, focus group discussions, and key informant interviews) were applied to triangulate results and minimize denial bias, which is a challenge when studying illegality. Results indicated that distance from markets and economic centers was the main driver for engagement in illegal activity, and distance from a center was also the main driver of poverty. Contrary to studies elsewhere, we found that poverty did not generally drive households' engagement in illegal trade. Only in Daru, the primary economic hub, where immigrants from the areas impacted by the Ok Tedi mine operations have resettled, were the poorest households likely to be involved in illegal trade, because they had no alternative sources of livelihood. Weak governance exacerbates the situation, which includes corruption, a lack of enforcement, and poor coordination among government levels, and a breakdown of traditional resource management systems. Respondents highlighted that current bilateral border agreements are outdated and cannot account for modernization, a globalizing economy, and communities' rapid transition to a cash economy. Our findings emphasize the need to find innovative governance solutions to manage this stressed social-ecological system, without which severe social, economic, and environmental repercussions could soon eventuate.
\end{abstract}

Key Words: coastal livelihoods; illegal wildlife trade; mixed-method research; poverty; transboundary; Trans-Fly region

\section{INTRODUCTION}

Burgeoning economic growth in Asia has led to its domination of global markets and an exponential increase in demand for natural resources (Zhang et al. 2008, Fabinyi 2012). Remote transboundary regions in developing countries often provide pristine resources that are being exploited to meet this everincreasing demand (Sanderson et al. 2002). Communities in these transboundary regions are on the periphery of political and economic influence, where there are low levels of enforcement and high levels of corruption (Tagliacozzo 2001, de Jong 2008). These marginal border regions are of concern to management authorities because of their porous nature, which allows unmonitored illegal activities, such as smuggling of natural resources, people, and goods, to thrive (Horstmann 2004). For example, the illegal trade of ivory has become the main source of income for militia groups operating in the border triangle of South Sudan, the Democratic Republic of Congo, and the Central African Republic (Nelleman et al. 2014). Similarly, the Balac Strait between the Philippines and Malaysia is of concern because of the escalating illegal exploitation and trade of live reef fish (Fabinyi et al. 2014).

The opening of illegal markets is reshaping livelihood strategies in these remote regions. Unprecedented exploitation patterns can jeopardize the long-term sustainability of natural resources that households typically rely upon, with an ultimate loss in biodiversity and well-being at the local level, and legally sourced export revenues for national governments (Milner-Gulland and Bennett 2003, Sadovy et al. 2003). Sudden opening of new markets has been found to affect communities previously isolated and economically marginalized through changes in the consumption patterns of natural resources; transitions to cash and credit-based economies; livelihood diversification; changes in income and income inequality (Kramer et al. 2009). Although communities are profoundly impacted by illegal activities involving natural resources, they are often excluded from any benefit. Being the lower level of the value chains, they receive very low returns compared to the final prices of traded products (Velasco 2010). Income from these activities rarely results in a long-term economic gain or in substantial community development. To protect natural resources and people's well-being from the expansion of illegal international trade requires an understanding of the motives of actors to engage in illegal activities at the local level (Keane et al. 2008, Milner-Gulland 2012). To date, management has largely focused on enforcement to deter these motivations (Roe et al. 2015a). More recently it has been recognized that efforts should instead engage communities to address the underlying systemic socioeconomic and cultural issues that drive trade, and identify alternative intervention options (Enck et al. 2006, Fabinyi et al. 2014), but there are few empirical examples of such an approach.

This paper presents an analysis of the drivers of the growing incidence of illegal trade and unsustainable use of natural resources in a remote transboundary region, the Torres StraitTrans-Fly region, which forms the borders between Papua New Guinea (PNG), Indonesia, and Australia. Coastal communities in the Western Province of PNG epitomize the challenges faced by people in resource-rich transboundary areas. PNG has witnessed rapid economic growth since mid-2000 mainly attributable to the extraction and export of its renewable and nonrenewable resources, with Ok Tedi mine in Western Province 
Fig. 1. The transboundary Torres Strait-Trans-Fly region, showing the 14 Papua New Guinea Treaty Villages and Daru, Merauke, the 14 Australian Torres Strait communities, and the Torres Strait Protected Zone.

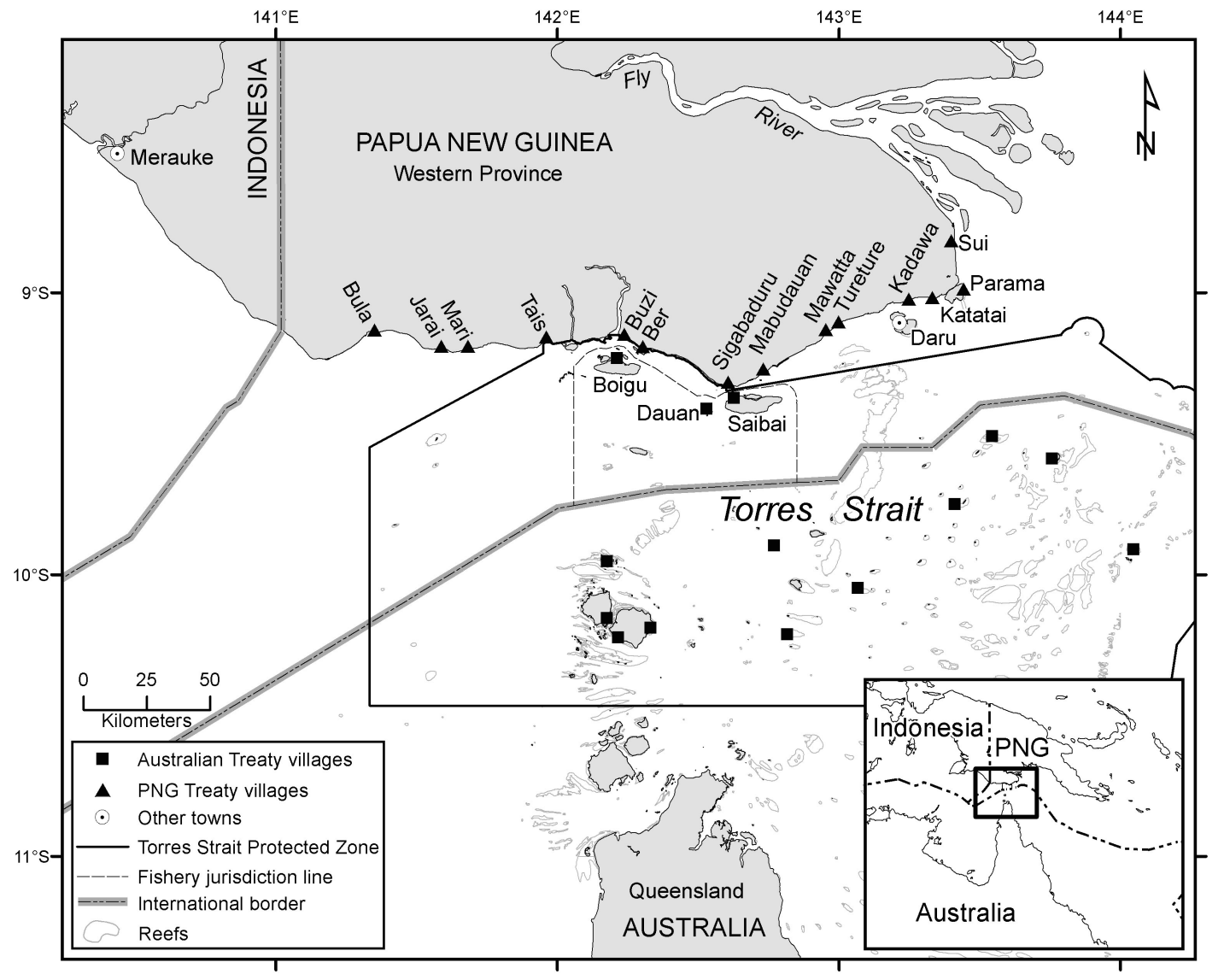

accounting for around $10 \%$ of government revenue (World Bank 2015). In spite of this, the province is considered one of the poorest regions in the world (McGillivray 2012, unpublished data). Illegal fishing and trading of marine products, coupled with rapid changes due to the political and economic instability, population growth in PNG, extractive development and exploitation, pollution of shared marine resources, and climate change are likely to increase the pressure on shared resources and consequently on the livelihoods of people living in the region (Butler et al. 2012a).

We address three questions in our research. First, what is the extent of Western Province communities' and households' involvement in illegal marine fishing activities and trade? Second, what are the drivers of their engagement in these activities? And third, what are the intervention points and solutions necessary to redirect households toward alternative, legal, and sustainable livelihood strategies? We also test and discuss methodologies suitable for analyzing sensitive issues linked to illegality.

\section{METHODS}

\section{Study area}

The southern coast of Western Province (hereafter the "South Fly") shares international boundaries with Indonesia's Papua
Province to the west and the Australian Torres Strait to the south (Fig. 1), a transboundary region we refer to as the Trans-Fly. The adjacent coastal waters contain diverse marine ecosystems of global biodiversity significance (Schug 1996), including high densities of endangered dugong (Dugong dugon) and marine turtles (Butler et al. 2012b). Exploitation patterns of marine resources in PNG and Indonesia are increasingly driven by rising incomes among Asian consumers, and rapid population growth (Foale et al. 2013). High value commodities such as dried sea cucumbers (bêche-de-mer [BDM]; Holothuria spp.), shark fins (mainly taken from Carcharhinus spp.), and swim bladders (maw) from barramundi (Later calcarifer) and jewfish (Protonibea diacanthus) are particularly in demand (Clarke 2004, Kinch et al. 2008, Anderson et al. 2011). Before the closure of BDM fisheries in 2009, PNG, and the South Fly in particular, was the third largest supplier of BDM to Asian markets in the world (Kinch et al. 2007).

The South Fly is dominated by extensive swampy plains that make infrastructure development and crop production difficult (Hanson et al. 2001). The district is among the least developed in PNG in terms of provision of basic infrastructures such as roads, health, and educational facilities (Asafu-Adjaye 2000). Because of the very poor soil and the economic disadvantage of the region 
compared to other parts of PNG, livelihoods and food security of the communities in the South Fly, especially from Sui to Mabudauan (Fig. 1), heavily depend on good and services provided by marine and other aquatic ecosystems (Allen et al. 2005). Population in the South Fly has likely more than doubled since 1980 (Butler et al. 2015a), exacerbated by internal displacement caused by the environmental impacts of the Ok Tedi mine in the headwaters of the catchment. Since the early 1990s sedimentation from the mine, and resultant downstream flooding, has driven inhabitants from the mid-Fly River catchment to resettle on Daru Island, the South Fly's economic and administrative hub (NSO 2010, Butler et al. 2015a). The resettlement of these new immigrants from the impacted areas has caused ongoing disputes with local communities over access and ownership of marine resources (Kinch et al. 2007). Population on Daru Island is estimated to be around 15,197 people while additional 5616 people live along 14 PNG coastal villages (Butler et al. 2012a).

In the last century, cross-jurisdictional arrangements mediated border disputes in the region and paved the signing in the 1970s of the contemporary bilateral agreements between the newly independent PNG and neighboring Australia and Indonesia. Recognizing the historical familial, cultural, and trading linkages among populations in the transboundary area, the agreements aim to protect the way of life of "traditional inhabitants," conserve the environment, and promote sustainable livelihoods (Torres Strait Treaty 1978, Basic Agreement between the Government of PNG and the Government of the Republic of Indonesia on Border Arrangements 1974). Under the Torres Strait Treaty, members of 14 Torres Strait Island communities and 14 village communities in the South Fly (hereafter the Treaty Villages) have been recognized as traditional inhabitants (Fig. 1). Traditional inhabitants are permitted "free movement and performance of lawful traditional activities in and in the vicinity of the Torres Strait Protected Zone" (Torres Strait Treaty Articles 11 and 12). However, they cannot "under the guise of free movement or performance of traditional activities, evade justice, entry illegally, and conduct practices prejudicial to effective immigration, customs, health and quarantine protection and control" (Torres Strait Treaty Article 16). Traditional activities in the Torres Strait Treaty "shall be interpreted liberally and in the light of prevailing custom" but it specifically rules out activities of a commercial nature (Torres Strait Treaty Article 1.1, Schug 1996). Similarly, under the PNG-Indonesia Basic Agreement and subsequent amendments, "nationals of the two countries who are domiciliated in the relative border areas may freely enter into and travel within the corresponding part of the border area of the other, solely for traditional and customary purposes" (Special Arrangements for Traditional and Customary Border crossings between the government of the Republic of Indonesia and the government of Papua New Guinea 1993, Article 2). Border residents are "permitted to engage in traditional and customary border trade within the respective border areas" (Special Arrangements Article 11.1). Fisheries products however are not listed in Annex A of the traditional goods exempted from duty or tax under the laws and regulations of the respective countries (Special Arrangements Article 11.2). Traded goods must not exceed US\$300 in value.

\section{Regulations governing resource harvest and trade}

Numerous international and national regulations govern the harvest and trade of natural resources in the Treaty Village communities and Daru. The PNG National Fisheries Authority (NFA) has lifted an eight-year moratorium on BDM fisheries in April 2017 and implemented the National Beche-de-Mer Fishery Management Plan 2016. In accordance with Clause 8(f)(i) of the plan, the fishery is open from 1 April to 30 September each year unless the total allowable catch in any provinces is reached before. Total allowable catch for the Western Province was set to $17 \mathrm{t}$ in 2017 and was reached within the first three months. No harvest is permitted in the remaining months. A management plan is also in place for the BDM fisheries in the Torres Strait Protected Zone in Australia. Management regulations in the Torres Strait Protected Zone are enforced by the Australian Fisheries Management Authority on behalf of the Protected Zone Joint Authority (AFMA 2011). Currently, total allowable catches for sandfish (Holoturia scabra) and surf redfish (Actinopyga mauritiana) are set at zero, while quotas are in place for all other commercial BDM species (AFMA 2013). The PNG NFA has also a Barramundi Fisheries Management Plan that imposes size limits and other spatial and temporal measures in PNG territorial waters (NFA 2004).

Export and quarantine of fish and their products in PNG are regulated under the National Agriculture Quarantine and Inspection Authority (NAQIA) Act 1997. In order to export to other countries, exporters are required to obtain the quarantine import conditions of the importing country before seeking certification from NAQIA. An animal health certificate is then issued for export clearance upon payment of a fee. Fish and fish products also need an export clearance by custom and an export permit by the NFA. In addition, items made from animals protected by the Convention on International Trade in Endangered Species require an export license from the PNG Conservation and Environmental Protection Authority (International Fauna and Flora Trade Act 1978).

Similarly, in Indonesia import and quarantine of fish and their products are regulated under several regulations. A health and safety certificate from the Quarantine is needed to export marine products, along with a letter of origin from the Department of Marine Affairs and Fisheries and in the case of sharks a letter of recommendation that certifies that traded species are not among the CITES listed species (Ministry of Marine Affairs and Fisheries decree N.18, 2013). In the Merauke district, trade of BDM has been banned since 2012 .

\section{Data collection}

The research team, consisting of six trained members of a local nongovernment organization (Bata CDF), a NFA officer, and the lead author, visited the Treaty Villages and Daru six times between September 2012 and July 2013. To address the three research questions, a mixed-method approach was used: focus group discussions (FGDs), key informant (KI) interviews, and household questionnaires (Appendix 1).

10 FGDs, five with women and five with men, were carried out to investigate characteristics of illegal livelihood strategies at the village level, the drivers of household involvement in these activities, and potential intervention points and solutions. Bula was selected to be representative of the western-most villages 
including Jarai, Mari, and Tais nearer the Indonesian border; Sigabaduru represented the central villages including Buzi and Ber; and Parama represented the eastern villages including Mabudauan, Mawatta, Tureture, Kadawa, Katatai, and Sui (Fig. 1). Two FGDs were carried out in each representative village, one with women and one with men. Four FGDs were carried out in Daru: two with resource owners (women and men separately), and two with Fly River immigrants (women and men separately). For each location the village head was asked to identify 5 to 10 adults who were engaged in marine resource use, and men and women were then invited to separate FGDs. Discussions were based on a set of open-ended questions or discussion points. The PNG team members acted as facilitators, and recorded groups' responses on flip chart paper.

Thirteen KI interviews were carried out with councillors and representatives of community organizations and groups to gain individuals' reflections on village-level engagement in illegal activities. KIs were selected based on their knowledge of the livelihoods in the villages. Potential KIs were contacted by the local NGO leader to arrange interviews, which were conducted by the lead author.

In all 14 Treaty Villages and Daru, 1100 household questionnaires were conducted, and covered between $36 \%$ and $75 \%$ of households (Appendix 2). However, in Daru, where there were safety concerns associated with entering some neighborhoods, only $19 \%$ of households were surveyed. The questionnaire was designed to investigate household livelihood strategies and sources of income, species harvested, and marketing strategies. In addition, indicators of living standards, education, and health were enumerated to calculate the multidimensional poverty index (MPI; Alkire and Santos 2010) as a potential driver of illegality. The questionnaire was first tested among the research team, and any ambiguous wording corrected. A random sampling design was applied to provide a cross-section of households: team members interviewed the head of every second household in smaller villages ( $\leq 70$ households), and every third household in larger villages and Daru ( $>70$ households).

\section{Research ethics and data triangulation}

Researching illegal activities poses numerous ethical and methodological challenges. Flawed conclusions, ultimately affecting management decisions, can arise as a consequence of the inherent sensitive nature of the topic, fear of prosecution (Gavin et al. 2010, Mateo-Tomas et al. 2012), and denial bias (Arvey and Cavanaugh 1995, Harrison 1997, Gribble et al. 1999). Biases can be limited by researchers guaranteeing confidentiality and neutrality to participants (Marquis et al. 1981, Gavin et al. 2010). Assurance of anonymity, trust in the interviewer, and correct wording of questions can also reduce response errors (Singer et al. 1995, Catania et al. 1996, Barnett 1998). Triangulation of data from mixed methods applied simultaneously can ultimately obtain the most accurate results (Pitcher et al. 2002, Gavin et al. 2010). The separate FGDs for men and women also allowed triangulation using both genders' perspectives.

To build trust and eliminate the perception of possible prosecution among potential participants, an initial community engagement phase was conducted in June-September 2012, involving three public forums in Daru, and publicity on local radio. The objectives of the study were explained, an amnesty from prosecution was guaranteed, and emphasis was given to the study's intention to understand the current dynamics of exploitation of marine resources to increase conservation and improve communities' livelihoods. The PNG team members were well respected locally, and were crucial in explaining project objectives to potential participants, and assuring the use of culturally appropriate protocols. To increase data reliability, indirect questioning techniques were applied. Also, the PNG team members were trained to create a "nonevaluative environment" during the surveys, whereby open and conciliatory dialogue is used to avoid an atmosphere of blame and potential recrimination (Steward and Shamdasani 1990). Verbal prior informed consent was sought from participants before commencing household questionnaires, FGDs, and KI interviews, during which confidentiality, anonymity, and the secure storage of raw data in Australia was guaranteed by the lead author.

\section{Data analysis}

To analyze the patterns of illegal activities at village level and Daru, household questionnaire results were collated to summarize frequencies of livelihood strategies, harvested and traded species, and markets or means of sale. To explore the drivers of engagement in illegal activities at household level, two hypothetical models were constructed. In the first model it was hypothesized that distance $(\mathrm{km})$ to the nearest market (measured as linear distance), livelihood strategies, and poverty are drivers of the illegal harvest and trade in marine resources (Fig. 2). In the second, we assumed that the relationship between poverty and illegal harvest and trade of marine resources was reversed such that illegal activities drive poverty. For these analyses, household poverty was calculated to be the composite of nine MPI indicators (Table 1). Distance was log transformed to emphasize differences among villages closer to markets.

Fig. 2. Schematic representation of the hypothetical models for illegal harvest and trade in marine resources. The solid lines explore the relationship between illegal activities and the other variables. The dashed line explores whether poverty drives illegal activities.

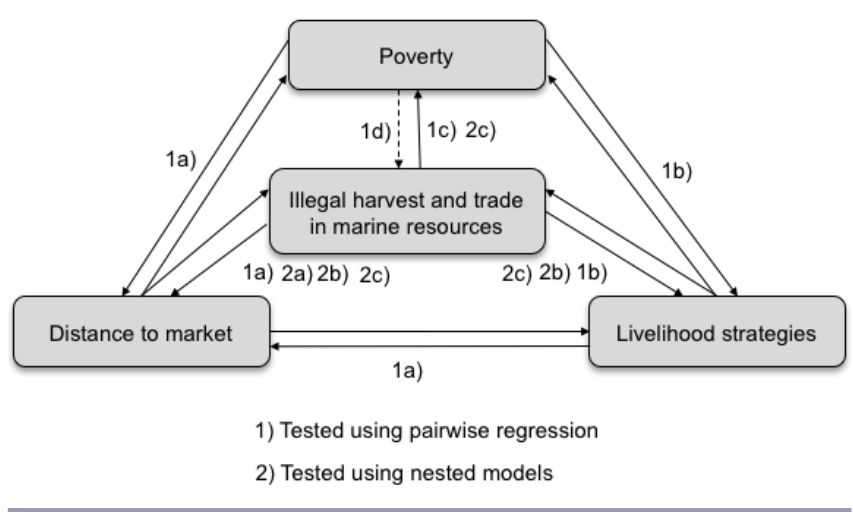

The primary analysis of the relationships in these models was via a series of linear regressions. To account for the effect of village, all models included a term for village (fixed or random as explained below). For quantitative response variables, we used ordinary least squares models. For binary response variables, we 
Table 1. Household attributes used to analyze relationships between illegal activities, poverty, distance to market, and livelihood strategies.

\begin{tabular}{|c|c|c|c|}
\hline Household attribute & Variable/indicator & Description & Variable type \\
\hline $\begin{array}{l}\text { Distance from nearest } \\
\text { market }\end{array}$ & $\begin{array}{l}\text { Linear distance }(\mathrm{km}) \text { from the nearest market in } \\
\text { Daru or in Boigu and Saibai in the Torres Strait }\end{array}$ & Log transformed $\mathrm{km}$ & Continuous \\
\hline \multirow[t]{9}{*}{ Poverty (MPI) ${ }^{\dagger}$} & Enrolment of children grade $1-8$ in the household & $\begin{array}{l}\text { Children aged 6-17 years in the household enrolled } \\
\text { in school }\end{array}$ & Binary $^{\ddagger}$ \\
\hline & Schooling status of household members & $\begin{array}{l}\text { At least one member of the household with five or } \\
\text { more years of schooling }\end{array}$ & Binary $^{\star}$ \\
\hline & Child death in the house & Death of one or more children in the household & Binary $^{\ddagger}$ \\
\hline & Presence of electricity in the house & Presence of fixed power or generator & Binary $^{\ddagger}$ \\
\hline & Presence of a safe water supply & $\begin{array}{l}\text { Connection to water supply or tank attached to the } \\
\text { house regularly refilled by rain }\end{array}$ & Binary $^{*}$ \\
\hline & Presence improved sanitation & $\begin{array}{l}\text { Presence of barrier around the toilet, and toilet not } \\
\text { shared to avoid contamination }\end{array}$ & Binary $^{*}$ \\
\hline & House building materials & House built of malaria-proof materials & Binary ${ }^{\ddagger}$ \\
\hline & Household cooking facilities & $\begin{array}{l}\text { Firewood is deprived, other cooking fuels not } \\
\text { deprived }\end{array}$ & Binary $^{*}$ \\
\hline & Household possessions & $\begin{array}{l}\text { Possession of boat and/or motor in working } \\
\text { condition and at least two communication } \\
\text { appliances. }\end{array}$ & Binary $^{\ddagger}$ \\
\hline \multirow[t]{4}{*}{ Livelihood strategies } & Employment status & $\begin{array}{l}\text { Presence of a part-time, full time, or casual job in } \\
\text { the household }\end{array}$ & Binary ${ }^{\S}$ \\
\hline & Number of income-generating activities & Household income diversification & Discrete \\
\hline & Fishing providing income & Harvesting of marine species for trade & Binary ${ }^{\S}$ \\
\hline & Hunting providing income & Harvesting of terrestrial species for trade & Binary \\
\hline \multirow[t]{3}{*}{ Illegal activities } & Illegal activities with Indonesian traders & $\begin{array}{l}\text { Engagement in illegal harvesting and/or trade of } \\
\text { species to Indonesian traders }\end{array}$ & Binary \\
\hline & Illegal activities with Torres Strait islands & $\begin{array}{l}\text { Engagement in illegal harvesting and/or trade of } \\
\text { species to Torres Strait islands }\end{array}$ & Binary ${ }^{\S}$ \\
\hline & $\begin{array}{l}\text { Illegal activities with Indonesia traders and/or } \\
\text { Torres Strait islands }\end{array}$ & $\begin{array}{l}\text { Engagement in illegal harvesting and/or trade of } \\
\text { species to Indonesian traders and/or Torres Strait } \\
\text { islands }\end{array}$ & Binary ${ }^{\S}$ \\
\hline
\end{tabular}

used generalized (logistic) linear models. For models with distances to markets as explanatory variables, village could not be included as a fixed effect because it was correlated with distance, i.e., all households in a village have the same distance values. In these cases we used linear mixed effects models that included village as a random effect. This added the assumption that village effects were normally distributed and introduced the potential for some spurious misallocation of variance between the distance and village effects. Because the sample of Daru household questionnaires greatly exceeded those from each Treaty Village, all data were subsampled such that no village was represented by more than 80 households.

There were two main groups of regressions. The first examined the pairwise relationships among household attributes, including (a) livelihood strategies, illegal activities, and poverty on distance; (b) illegal activities and poverty on livelihood strategies; (c) illegality on poverty (first hypothetical model); and (d) poverty on illegality (second hypothetical model). The second group, for the second hypothetical model, was a sequence of nested models to test whether systemic issues, i.e., poverty, explained variation in illegal activities in addition to that explained by proximate issues, i.e., distance and livelihood strategies. These were (a) illegal activities on distance; (b) illegal activities on distance and livelihood strategies; and (c) illegal activities on distance, livelihood strategies, and poverty. Tests were repeated for Daru alone, which had a low average MPI, i.e. less poverty, low illegality, and zero distance to the nearest market.

Results from the statistical analysis were triangulated with the FGDs and KI interviews. Quotes from interviews were used to explain and support the statistical relationships. Key statistical relationships between household attributes and drivers were synthesized using causal loop diagrams, which graphically describe circular chains of cause-and-effect in a system (Kirkwood 1998, unpublished manuscript, http://www.public. asu.edu/ kirkwood/sysdyn/SDIntro/preface.pdf).

\section{RESULTS}

\section{Involvement in illegal activities}

Income generating activities in each community depended on their natural resource base and market availability. Fishing was the main source of income in the western and eastern villages, while in the central villages households primarily sold handcrafts to the adjacent Australian Torres Strait Islands of Saibai, Dauan, and Boigu (Fig. 3). Because of the absence of local reefs, the western and central villages rely on freshwater fish and a guild of 
Fig. 3. Sources of income in the village clusters as a proportion of household questionnaire responses. Western villages are Bula, Jarai, Mari, and Tais; eastern villages are Buzi, Ber, and Sigabaduru; eastern villages are Mabudauan, Mawatta, Tureture, Kadawa, Katatai, Parama, and Sui.

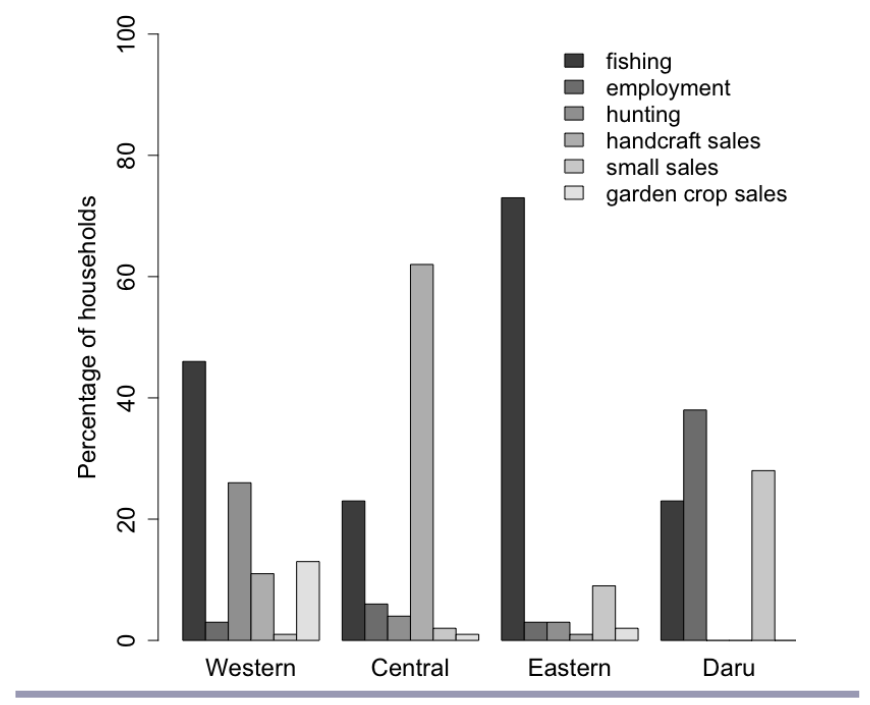

coastal and estuarine fish species, such as barramundi, jewfish, sharks, and rays (Dasyatis spp.), usually taken with gillnets, and mud crabs (Scylla serrata; Fig. 4). The eastern villages and Daru are closer to coral reef habitats, and consequently harvest a wider range of species, such as tropical rock lobster (Panulirus ornatus), barramundi, jewfish, reef, coastal, and freshwater finfish, shellfish, sharks, and rays. These latter villages have less land available for subsistence activities and thus have a higher dependence on marine resources for their food security. Some dugongs and marine turtles are caught with spears or as bycatch in gill nets. Sea cucumbers are also harvested, as discussed during the FGD and KI interviews, however respondents did not openly admit they were personally infringing the moratorium during the household surveys.

Overall $48 \%$ of respondents directly confirmed their involvement in the illegal fishing and trade of marine resources with the Indonesian buyers, with higher numbers of respondents in the western and eastern villages (68\% and $60 \%$, respectively) than in the central villages and Daru (43\% and $28 \%$, respectively). In descending order of value, FGDs respondents reported that species illegally harvested and/or traded with Indonesia were BDM, shark fins, barramundi and jewfish bladders, barramundi and jewfish meat, crabs, and shellfish. These activities breached a range of international and domestic regulations (Appendix 3). There were differences in the patterns of species harvested between the village groups, and their markets or points of sale (Fig. 5). For western villages, because of the great distance from the market of Daru $(>100 \mathrm{~km})$, the primary point of sale is Indonesian traders who travel by boat across the PNG-Indonesia border from the town of Merauke, approximately $90 \mathrm{~km}$ away, and visit PNG coastal villages to trade goods with villagers. In the last decade, $\mathrm{PNG}$ villagers have also established fishing camps along the coast where they solely harvest species for the trade with Indonesian traders. Some villagers also cross the border by boat and sell shark fin, fish bladders, and crabs directly to buyers in Merauke. The central villages travel to the Torres Strait Islands of Saibai, Dauan, and Boigu to sell barramundi meat, crabs, and shellfish, which are $<25 \mathrm{~km}$ away. There is also some trade of barramundi bladders with Indonesian traders, and shark fin is traded with PNG middle-men based in the village. The eastern villages are closest to Daru $(<30 \mathrm{~km})$. The eastern villages and Daru primarily sell finfish, shellfish, and crabs in the Daru market and trade rock lobsters, barramundi, and jewfish meat and bladders and shark fins with licensed buyers in Daru. The high-value products such as BDM, shark fin, and fish bladders are also traded with Indonesian traders. Fly River immigrants, especially men, have recently relocated into fishing camps along the coast. They mainly trade shark fins and fish bladders with the Indonesian traders.

Fig. 4. Harvested species as reported by respondents during the household surveys, presented as percentages of respondents who mentioned each group.

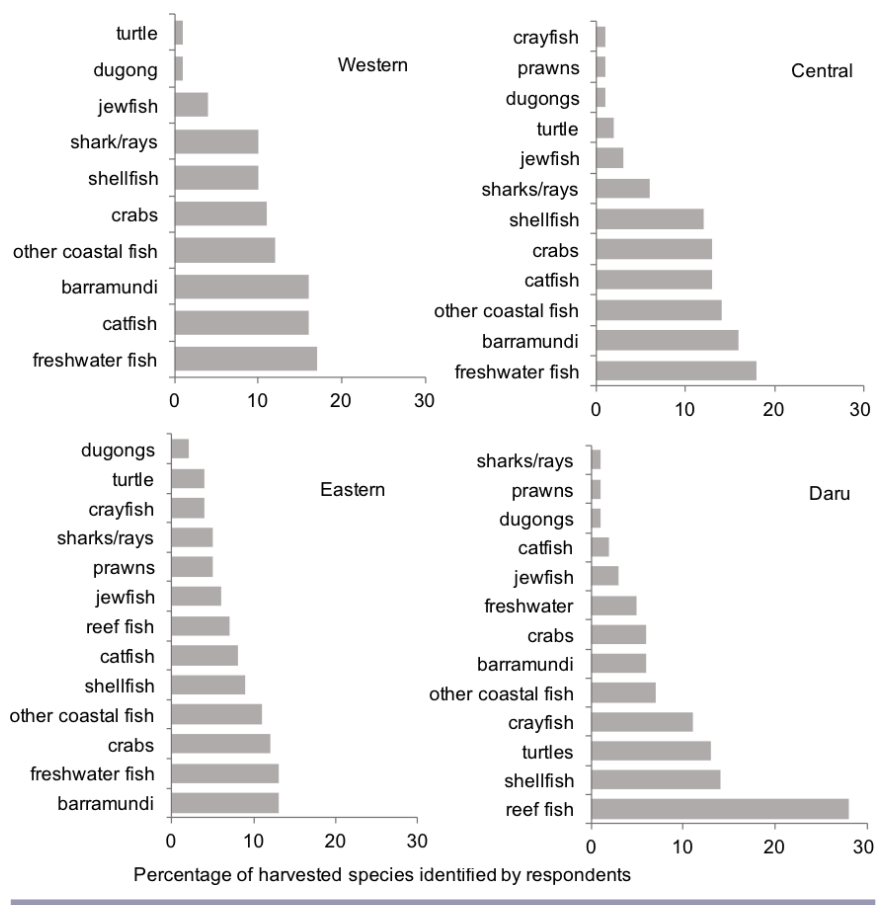

Men and women's FGDs and KIs from the eastern villages and Daru indicated that the operations driven by the Indonesian traders mainly focus on BDM, which is still considered to be the most lucrative product, even during the NFA's moratorium. For example, a woman in Daru stated the following:

Before we never catch sea cucumbers, there was not market, people did not know ... but now the status of the sea cucumber has become something in term of money, it has become gold in the sea, so people go out to get them just for the sake of selling them... right now the market is very, very expensive. 
Fig. 5. Marine products that are harvested and/or traded with the Indonesian buyers and Torres Strait Islanders, listed in descending order of value. Both illegal and legal markets or points of sale for western, central villages, eastern villages, and Daru are included.

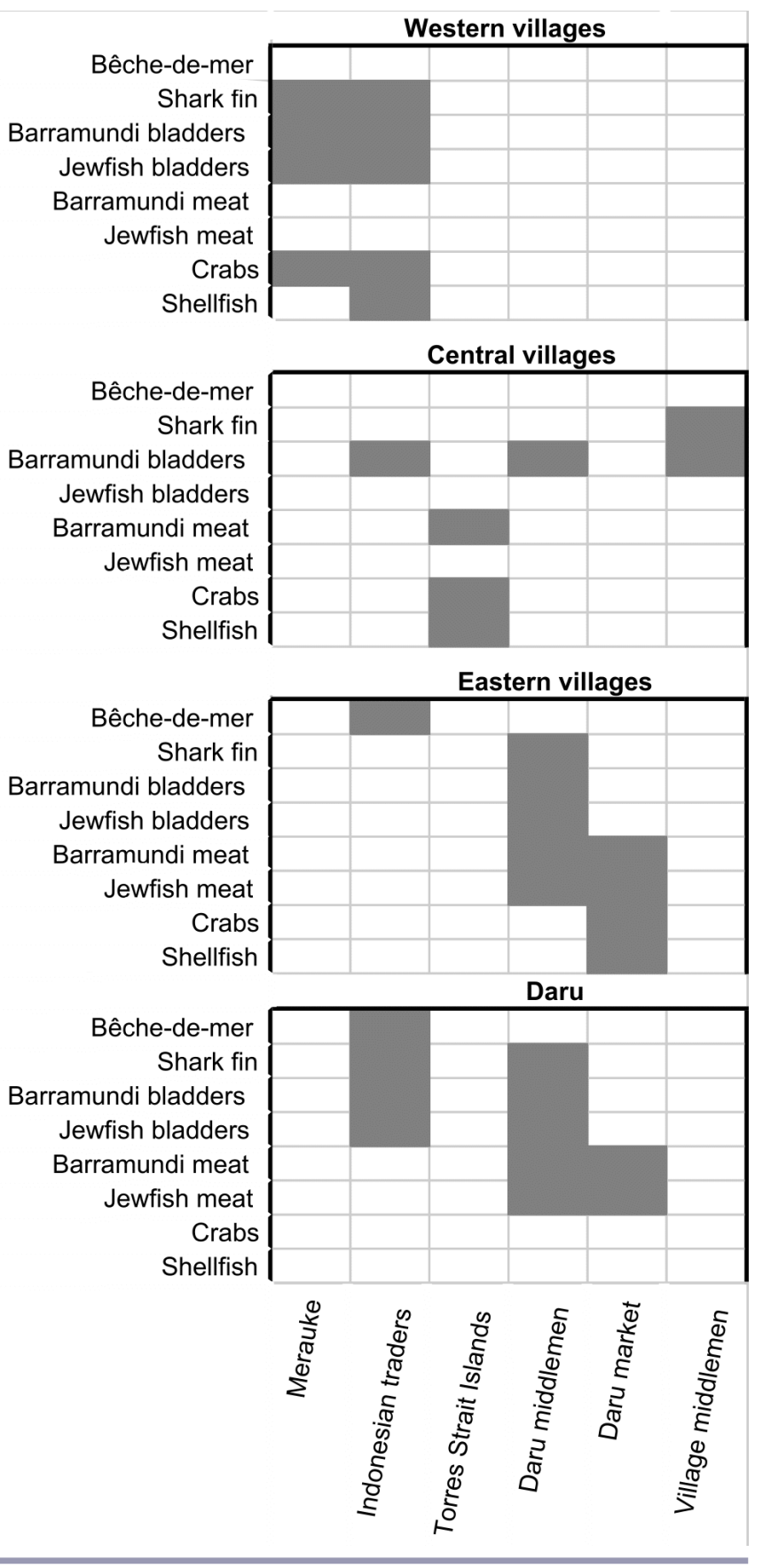

Closer to Daru, specific coastal communities are more heavily involved in the trade. The operations with the Indonesian traders were described as follows by one KI (village names are masked to maintain anonymity): ...sea cucumbers, star fish, fish balloons [bladders], there is no one operating now [locally]... When the sea cucumber guys [Indonesian traders] come, we sell directly to them... they are based in $X$... people take [products] to $X$.

In the western villages, FGDs and KIs agreed that the only available markets are the Indonesian traders or Merauke. Men are mainly involved in the trade, and women in processing:

[Barramundi and jewfish] we eat them or throw away,
we take them to the mangroves and bury it. We [women]
do not do bladders, only men, they do the selling with
Indonesian buyers. We [women] just dry them, also
shark fins. We only sell to buyers crabs, only mud crabs.

Drivers of illegal activities

For pairwise comparisons (relevant to both hypothetical models), household questionnaire data on livelihood strategies, illegal activities, and poverty were regressed against distance from the nearest domestic or Australian market. The only statistically significant correlations were for illegal activities with Indonesia, hunting, and poverty, which were positively related to distance from the nearest market (Table 2). For the regressions of illegal activities and poverty against livelihood strategies, illegal activities were positively correlated with the number of income generating activities, fishing, and hunting (Table 3). For Daru alone, these relationships were also evident, and poverty was also positively correlated to fishing (Table 3 ). For the regression of illegal activities against poverty (first hypothetical model) the only statistically significant correlation was for illegal activities with Indonesia, which was positively correlated with poverty only in Daru (Table 4).

For the nested mixed effects models of illegal activities, livelihood strategies explained significant variation in illegal activities in addition to that explained by distance (Table 5). The addition of poverty to the model (illegal activities on distance and livelihood strategies) did not significantly improve the model. Also for Daru alone, poverty did not significantly improve the regression of illegal activitities on livelihood strategies (Table 5). The variation in illegal activities explained by poverty was therefore largely explained by livelihood strategies.

In Daru and the eastern villages, FGDs participants acknowledged an increasing trend in illegal, unlicensed fishing on reefs on the Australian side of the Torres Strait Protected Zone for BDM, because stocks in PNG territorial waters adjacent to the South Fly have been overexploited:

When we were little we went down here [Daru home reef] and there were plenty [sea cucumbers], but since we started harvesting in 1989, it went a bit further, then we never go to the Australian side to fish. Maybe 10 or 15 years we never went far to fish and then we started going further [to reefs around Daru and along the coast ], then Auwo Maza areas [Warrior Reef on PNG side], and then later we have to pass down to Silver Reef [close to the border with Australia] and further down, and then right to the border, Moon Passage, and now today they are going on to the other side of the border fishing. 
Table 2. Linear mixed effects models that tested the relationships between household-level occupation, illegality, and poverty against the explanatory variable, distance to the nearest market. A random effect term was included for village. For each distance explanatory variable, the table shows the parameter estimate and significance. The methods used are linear mixed effects models (LMM) and generalized (logistic) linear mixed effects models (GLMM). Goodness of fit measures are $\mathrm{R}^{2}$ (LMM) and area under the curve, or AUC (GLMM). Bold indicates a statistically significant relationship $(\mathrm{p} \leq 0.05)$.

\begin{tabular}{|c|c|c|c|c|}
\hline$\underline{\text { Response }}$ & Nearest market & $p$ & $\mathrm{AUC} / R^{2}$ & Method \\
\hline Employment & -0.55 & 0.2 & 0.85 & GLMM \\
\hline Income activities & -0.13 & 0.6 & 0.07 & LMM \\
\hline Fishing income & 0.30 & 0.5 & 0.83 & GLMM \\
\hline Hunting income & 0.76 & 0.014 & 0.77 & GLMM \\
\hline Illegal activities & 0.34 & 0.3 & 0.74 & GLMM \\
\hline Illegal activities, Indonesia & 0.50 & 0.04 & 0.72 & GLMM \\
\hline Illegal activities, Torres & 9.33 & 0.7 & 0.89 & GLMM \\
\hline \multicolumn{5}{|l|}{ Strait } \\
\hline $\begin{array}{l}\text { Multidimensional poverty } \\
\text { index }\end{array}$ & 0.37 & $<0.001$ & 0.10 & LMM \\
\hline
\end{tabular}

Border crossing into Indonesia and the Torres Strait Islands is common in the western and central villages, respectively, as evidenced by Sigabaduru and Bula respondents. However, although they were aware of the conditions of the two treaties and the laws regulating harvest and trade of marine resources, they did not perceive cross-border commercial trade as illegal. Respondents in Daru attributed illegal harvesting and trade to a failing governance system:

They [people in the communities] have been bribed, they have phone numbers and they can communicate with them [Indonesian buyers]... officers are also been bribed... Fisheries [authorities] on this island know about it and they cannot do anything.

Lack of awareness of the social and ecological impacts of illegal and unmonitored fishing and trade was another driver of involvement in illegal activities, as reported by FGDs in Daru and Parama. One participant stated the following:

In the 1980s, 1990s, something was done to address the issue... There was a lot of information done, since then nothing. We have the fisheries inspectors now, but what are they doing? Before the fisheries inspector and his wife would go out and say this is the law or this is the reason ... The fisheries officer had a committee from each community helping them in doing awareness.

In Daru, the influx of Fly River immigrants has exacerbated people's dependence on marine resources, resulting in heightened tensions over resource ownership between traditional inhabitants and the immigrants. This tension has been escalating over recent years because of development of the lucrative illegal trade. One traditional inhabitant explained:

We have people all around Daru that are from inland, they are the ones using our resources. They are jobless and our resource owners are just sitting down and observe. They should be the ones to stand up and say no, you cannot sell fish, you go back to your own villages. They are destroying our reef, the other people go out every day...

Fly River immigrant FGD participants concurred:

The traditional fishing grounds are in our villages [Fly River] but now we go fishing in Auwo Maza [the PNG portion of Warrior Reef], this is the main fishing area now. And the reefs around Daru...

This illegal fishing, it is just because of, you know, coming down to this township and there is not opportunity, no nothing. And then what people do is just fishing.

A traditional inhabitant in Daru also considered the limitations of the Torres Strait Treaty to be a contributory factor:

When this treaty was signed, without realizing these people [authorities] that our population is growing and that our fishing grounds have become very narrow. Because our fishing grounds are narrow and our young people are growing and the population is growing and is a problem to become a fisherman where there is not fish...

Growing social problems were also attributed to the lucrative returns derived from illegal activities, and the attractions of earning more. Women FGD participants in Daru were concerned that the money earned by young boys and men from the trade with Indonesian buyers was used for recreation instead of households' primary needs:

The villages and communities are facing a lot of problems today. Our children under age are drinking, smoking, and even getting married, and not schooling. Our school age children are making money for themselves in order to drink and smoke and do what they want to do. Even young girls making money out of it, prostitution. That is the result of the sea cucumber race.

As soon as the [Indonesian] buyers pay, they [fishermen] share with them... then the family buying their food... ok that is from the women point of view... but the worst part is men then go and spend their money in drinking.

Causal loop diagrams synthesized the significant relationships between household attributes. In the villages, distance from a market and main economic center is the primary driver of poverty and involvement in illegal activities (Fig. 6). The further a household is from a market, the more likely it is to be involved in illegal trading with Indonesian buyers. Livelihood strategies also drive households' illegal activities, with those already undertaking hunting or fishing and with a higher number of income generating 
Table 3. Linear regression models that tested the relationships between household-level illegality and multidimensional poverty index (MPI) against the explanatory variables of occupation (employment status, number of income-generating activities, fishing, or hunting providing income), divided into (a) all households and (b) Daru only. For each occupation explanatory variable, the table shows the parameter estimate and significance. The methods used are linear models (LM) and generalized (logistic) linear models (GLM). Goodness of fit measures are $\mathrm{R}^{2}$ (LM) and area under the curve, or AUC (GLM). Bold indicates a statistically significant relationship $(\mathrm{p} \leq 0.05)$.

\begin{tabular}{|c|c|c|c|c|c|c|c|c|c|c|}
\hline \multirow[b]{2}{*}{ Response } & \multicolumn{2}{|c|}{ Employment } & \multicolumn{2}{|c|}{ Income activities } & \multicolumn{2}{|c|}{ Fishing income } & \multicolumn{2}{|c|}{ Hunting income } & \multirow[b]{2}{*}{$\mathrm{AUC} / \mathrm{R}^{2}$} & \multirow[b]{2}{*}{ Method } \\
\hline & Effect & $p$ & Effect & $p$ & Effect & $p$ & Effect & $p$ & & \\
\hline $\begin{array}{l}\text { (a) All } \\
\text { Illegality Indonesia }\end{array}$ & & & & & & & & & & \\
\hline Illegality, Indonesia & 0.03 & 0.9 & 0.19 & 0.04 & 1.20 & $<0.001$ & 1.05 & $<0.001$ & 0.77 & GLM \\
\hline $\begin{array}{l}\text { MPI } \\
\text { (b) Daru only }\end{array}$ & -0.34 & 0.1 & -0.05 & 0.3 & 0.20 & 0.2 & 0.03 & 0.8 & 0.09 & LM \\
\hline Illegality, Indonesia & -0.31 & 0.5 & 0.73 & 0.0012 & 1.50 & 0.0002 & 1.47 & 0.003 & 0.82 & GLM \\
\hline MPI & -0.19 & 0.2 & 0.13 & 0.13 & 0.62 & 0.0003 & 0.34 & 0.2 & 0.08 & LM \\
\hline
\end{tabular}

activities more likely to be engaged. However, poverty does not drive involvement in illegal activitities. In Daru only poverty does directly drive involvement in illegal activities (Fig. 7). Poorer households, which are often Fly River immigrants, are more likely to be involved, and these are probably already engaged in hunting and fishing, and have a wide range of income generating activities. However, livelihood strategies are still the main driver, driving both illegal activities and poverty.

Fig. 6. Causal loop diagram of the main drivers (+ positive, negative) of illegal activities (fishing and/or trading) in the South Fly Villages.

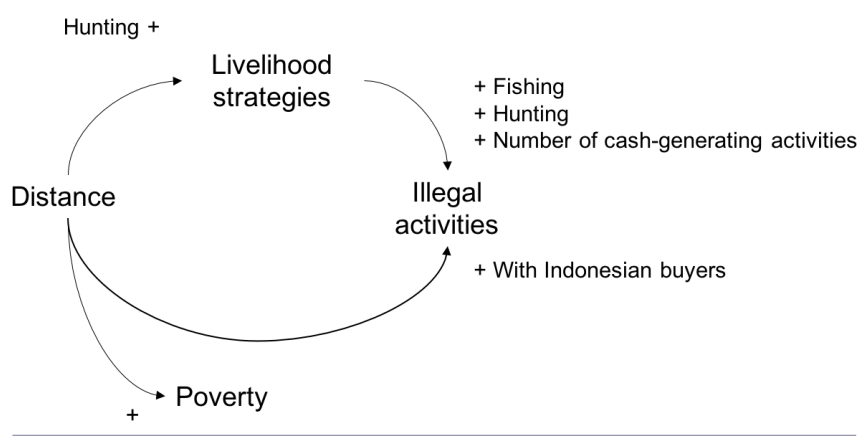

Fig. 7. Causal loop diagram of the main drivers (+ positive, negative) of illegal activities (fishing and/or trading) in Daru.

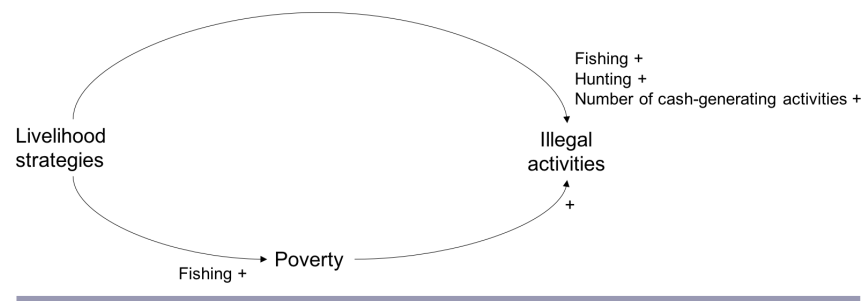

Because they are based on the findings of the statistical regressions, the causal loop diagrams do not capture the broader contextual factors that create or exacerbate conditions for livelihoods. In this regard, the FGDs and KIs highlighted the role of the Ok Tedi mine disaster in the 1990s and the resultant influx of Fly River immigrants to Daru. Lack of ownership of the natural resources immigrants exploit have meant they have to survive on subsistence activities and without a source of cash income. However, lack of alternative livelihoods in Daru and the adjacent coastal villages has forced the immigrants to fish locally to meet their food security needs. Competition for marine resources has caused conflict with resource owners and led to the overexploitation of marine resources such as BDM. All these factors have driven illegal harvesting in the Torres Strait Protected Zone. Other indirect drivers identified by respondents in the central and eastern villages and Daru were a failing governance system, lack of awareness of fishing regulations and management, the inflexibility of the Torres Strait Treaty, and the financial incentives from engaging in the lucrative illegal trade.

\section{Intervention points and solutions}

In Daru and the eastern villages, where the two main problems were illegal harvesting in the Torres Strait Protected Zone to obtain BDM for sale to Indonesian traders, and conflicts between traditional inhabitants and Fly River immigrants over resources, FGD participants of both kinds agreed on the need to raise awareness:

We have to make our awareness in the villages, especially to people who go out and the resource owners have to be more on... The more we harvest on those things the more they tend to finish and it is all gone. (traditional inhabitant)

To address this issue [illegal fishing and overharvesting], research is needed, awareness, that's service messages, program, to be able to educate each fisherman and fisherwoman. (Fly River immigrant)

Traditional inhabitants also saw development of, or enforcement of existing community-based regimes and coordination among different levels of government and local communities as priorities. Men in the Daru and Parama FGDs were particularly interested in enforcing or establishing community-based laws to manage resources, citing ongoing initiatives in the neighboring Torres Strait Islands as potential models. A female FGD respondent expressed this recurring sentiment:

Make awareness of the very importance of these marine resources, maybe talk to them [village people], the resources just disappearing, and nobody is doing 
Table 4. Regression models that tested the relationship between household-level illegality against multidimensional poverty index (MPI) for (a) all households and (b) Daru only. The table shows the MPI parameter estimate and significance. All models (except that for Daru only) included village as a fixed effect. The $p$ value is for the ANOVA of the additional variance explained by adding the MPI variable to the nested model that included place only. Bold indicates a statistically significant relationship $(\mathrm{p} \leq 0.05)$.

\begin{tabular}{lccccc}
\hline \hline Response & MPI & $p$ & AUC & Change & Method \\
\hline $\begin{array}{l}\text { (a) All } \\
\begin{array}{l}\text { Illegality, Indonesia } \\
\text { b) Daru only }\end{array}\end{array}$ & 0.05 & 0.4 & 0.72 & 0 & GLM \\
\begin{tabular}{l} 
Illegality, Indonesia \\
\hline
\end{tabular} & 0.39 & $\mathbf{0 . 0 0 0 4}$ & 0.66 & 0.16 & GLM \\
\hline
\end{tabular}

anything, for the sake of our next generations, we have to stop this buyers illegally crossing the border. If we are really serious of thinking of our resources we need to stand up and work with NFA we cannot just sit back and let NFA, they are doing their job, but they are not doing the job unless we are allowing them to come into our resource areas... we need to stand up with NFA.

A Fly River immigrant in Daru suggested that developing alternative livelihoods was a necessity:

\begin{abstract}
If the government comes in and gives employment to everybody residing here under Daru census division, that will be also good. Secondly give eviction notice for the people who belong to different LLG [Local Level Government ]. The area was only allocated to 5000 people today we are almost 30,000 plus... Because people are here overcrowding and the employment is not there and they have to survive and the only mean is to go up there [Warrior Reef].
\end{abstract}

Alternative markets and value chains were proposed by FGD participants in the eastern and central villages. Traditional inhabitants in Daru also supported establishing new legal markets for fishery products, so that income from fishing could be increased and focus diverted from illegal activities:

Maybe you find a fish market or something and you sell it, maybe we can sell them to secondary school here, hotels, hospitals. Certain people are willing to do their own freezer, ask for the government assistance, and then whatever is stored in the freezer send it to places like Kiunga, Tabubil and Camusi, even Moresby.

Others suggested adapting existing Torres Strait Treaty arrangements. In Sigabaduru, where people rely mainly on trading with the neighboring Torres Strait Islands, respondents proposed a local market in Saibai that they could freely access, or a market in Sigabaduru that could be accessed by Torres Strait islanders. Respondents in the western villages were more hesitant in providing solutions to the problem of illegal trade with Indonesian traders and Merauke.

\section{DISCUSSION}

Remote transboundary regions in developing countries often contain abundant natural resources, and many of these resources are being overexploited to supply an ever-increasing demand from Asia, often via illegal cross-border trade (Fabyini et al. 2014). Resulting changes in exploitation patterns and livelihood strategies can have long-term impacts on communities' well-being
Table 5. Nested regression models that tested whether higher level drivers explained variance in illegality in addition to that explained by lower level drivers. The models were logistic mixed effects models (all villages) and logistic regression models (Daru only). The table shows the significance of the extra variance explained as each group of explanatory variables was added to the model that included all of the previous groups, e.g., as multidimensional poverty index (MPI) was added to the model that included distance and occupation. For "All villages," the "null" model included the village random effect.

\begin{tabular}{|c|c|c|c|c|c|}
\hline \multirow[b]{2}{*}{$\begin{array}{l}\text { Explanatory } \\
\text { group }\end{array}$} & \multirow[b]{2}{*}{ d.f. } & \multicolumn{2}{|c|}{ All villages $(\mathrm{n}=776)$} & \multicolumn{2}{|c|}{ Daru $(n=345)$} \\
\hline & & AUC & $p$ & AUC & $p$ \\
\hline $\begin{array}{l}\text { (null) } \\
\end{array}$ & & 0.74 & & 0.5 & \\
\hline distance & 2 & 0.74 & 0.07 & & \\
\hline occupation & 4 & 0.83 & $<0.001$ & 0.82 & $2 \mathrm{e}^{-11}$ \\
\hline MPI & 1 & 0.83 & 0.7 & 0.83 & 0.14 \\
\hline
\end{tabular}

and the trajectories of their social-ecological systems. Understanding the systemic issues that drive households to engage in illegal activities in transboundary regions is a prerequisite for designing effective interventions, but is rarely carried out because of the secretive nature of illegal activities and the remoteness of these regions (Duffy et al. 2016). Studies such as ours are the first step toward developing incentives, rather than enforcement alone, which can deter households' engagement in illegal trade, and encourage sustainable exploitation patterns (Rosen and Smith 2010, van Vliet 2011, Roe 2015).

\section{Involvement in illegal activities}

According to respondents in the South Fly, western and eastern communities were more dependent on fishing for their incomegenerating livelihoods and had higher levels of involvement in illegal activities with the Indonesian buyers. Their reduced livelihood options depended on a lack of markets in the case of the western villages and in a reduced resource base in the case of eastern villages. When more profitable cash-generating activities were present, as in the central villages and part of Daru, people were less involved in the trade with the Indonesian buyers. Central villages mainly relied on the trade of handcrafts with the Torres Strait islands while part of the residents in Daru could engage in small-scale businesses and employment. The role of alternative livelihood projects in achieving conservation goals while improving communities' livelihoods have been long debated (Wright et al. 2016). Often the effectiveness of such projects has 
been questioned but empirical studies assessing such projects are scarce (Wicander and Coad 2015, Roe et al. 2015b). The different behavior toward illegal activities observed in various South Fly communities is an indication that alternative livelihood projects could disincentive involvement in illegal wildlife harvest and trade under appropriate conditions.

Involvement in the trade with Indonesian buyers had a negative impact on the whole social-ecological Trans-Fly system. Traditionally, as also in neighboring Torres Strait, South Fly communities do not have the notion of the finite nature of marine resources, because of the high marine productivity of the area and the low human population (Johannes and MacFarlane 1991). Concerns were however expressed for the overexploitation of some of the targeted resources, such as BDM. BDM is known to be highly vulnerable to overexploitation, and cases of overexploitation following the opening of fisheries for the Asian markets have been reported all over the world (Anderson et al. 2011). The 2009 moratorium introduced by the NFA has been trying to conserve this important resource. Continuous unmonitored exploitation of this resource will have negative social-ecological impacts on the Trans-Fly system, with a loss in ecosystem services and income and higher levels of food insecurity (Kinch et al. 2008, Anderson et al. 2011). The socioeconomic impacts of overexploitation of marine resources can be more severe for communities in Daru and surrounding villages, which are highly reliant on them. Respondents also reported a breakdown of the customary marine tenure following immigration, consistent with similar situations in other parts of PNG (Cinner 2005). Customary marine tenure breakdown further increases the vulnerability of exploited species (Watson 1989). Respondents also expressed their concern for the breakdown of the traditional social systems and a rise in prostitution and crime, coupled with widespread corruption. Women were particularly vocal in discussing how income from illegal activities was not resulting in an evident economic gain for involved households nor in long-term community development. Although earnings from the illegal trade of wildlife provide a substantial income, there is not economic gain for households because of the unpredictability of the source and the volatility of earned cash (van Vliet 2011). Income earned from the illegal wildlife trade often does not contribute to food security but is spent in recreational items such as alcohol (Coad et al. 2010).

\section{Drivers of illegal activities}

Distance from the markets and economic centers was the main driver for the engagement of people in illegal activities. Distance from a main economic center was also the main driver of poverty. Contrary to a body of literature on the illegal trade of natural resources, mainly conducted in Africa (Lindsey et al. 2011, Twinamatsiko et al. 2014), we found that poverty did not significantly drive households' engagement in the illegal trade of marine products. In the villages along the coast, people's involvement in illegal activities was opportunistic. Only in Daru, where Fly River immigrants resettled, were the poorest households likely to be involved in the illegal trade. In this case, a limited resource base and lack of ownership of natural resources prevent immigrants to survive on subsistence activities, driving them to engage in illegal activities. Poor households in Daru, particularly immigrants, are more reliant on the illegal activities for their food security.
The strong correlation between distance from the markets, with their services and infrastructures, on one hand and engagement in illegal trade and poverty on the other is largely consistent with what is found in other studies in developing countries (Twinamatsiko et al. 2014). Lack of infrastructure and inaccessibility to markets prevent remote communities from engaging in the cash economy (Gibson and Rozelle 2002). However, in remote communities located in transboundary regions, these opportunities are provided by their proximity to neighboring countries and international markets (Velasco 2010). Illegal activities in transboundary regions are common economic activities, and are often part of an historical trade network forged before the delineation of current borders (Tagliacozzo 2001). Also, traveling traders, described by Berkes et al. (2006) as "roving bandits," provide a linkage between remote communities and the global economy. Lack of infrastructure and inaccessibility to markets have previously been found to drive poverty in remote PNG communities (Gibson and Rozelle 2002), and in the transboundary region of the Trans-Fly, traditional inhabitants cross the border to take advantage of Australian health facilities and other services in the Torres Strait Islands (Lokuge et al. 2012). These patterns are corroborated by our study, where poverty was found to be greater with increasing distance from both the domestic and the Australian markets.

The lack of correlation between poverty and involvement in illegal trade in the villages of the South Fly supports Duffy et al.'s (2016) view that complex systemic social, economic, and political inequalities play a major role in motivating people's involvement in illegal activities, rather than material deprivation. Interestingly, we observed a different pattern in Daru, where illegal trade was indeed found to be related to poverty. The Daru population was estimated to be 15,197 in 2011, with a density well above 100 persons $/ \mathrm{km}^{2}$ (Butler et al. 2012a), which is a sustainability threshold for many PNG islands under current levels of technology (Butler et al. 2014). Overpopulation, lack of employment opportunities, inadequate services and infrastructure, and a scarcity of terrestrial resources has led to legal and illegal overexploitation of marine resources. Impoverishment due to a limited terrestrial natural resources and a lack of employment opportunities, and subsequent dependence on marine resources and trade was observed particularly among Fly River immigrants in Daru, who live in settlements with no water, sanitation, cooking facilities, and have low education levels.

\section{Intervention points and solutions}

Participants' proposed short-term solutions were to improve the efficiency of current legal value chains, and to find alternative value chains for marine products that are illegally traded. Suggested long-term solutions were the provision of alternative incomes not based on the exploitation of natural resources. Our analysis also suggested that more profitable alternative incomegenerating activities might decrease the involvement in illegal activities. Respondents recognized, however, that to be successful such interventions should be part of an integrated approach with the reintroduction of customary marine tenures and the establishment of community-based initiatives, such as organized cooperatives and community-based management, to cater for the fast changing social-ecological system. In neighboring Torres Strait communities, a functional participatory governance system, associated with income from welfare and commercial 
fishing are effective deterrents against illegal trade (Busilacchi et al. 2013, Butler et al. 2015b). Another proposed intervention was the establishment of transboundary comanagement arrangements. An adaptive, multilateral agreement involving PNG, Australia, and Indonesia is necessary for the establishment of collaborative discussions that can manage the rapidly changing dynamics of this transboundary social-ecological system. The failure of the current PNG governance system appears to be a primary systemic cause of the declining trajectories in human and natural resource condition (Butler et al. 2015a). The current Treaties are also deemed to be outdated, and cannot account for modernization, a globalizing economy, and communities' rapid transition to a cash economy (O’Donnell 2006).

\section{CONCLUSION}

The debate about how to effectively intervene to combat the illegal harvesting and trade of natural resources has been a focus of conservation, development, and academic arenas in the last decade. Results from our empirical study show that a mix of shortand long-term interventions are necessary in the South Fly. Results from the present study suggest that alternative livelihood interventions could be effective in diverting communities from illegal wildlife trade while improving the livelihoods in the communities. However, it is also clear that within our study area a single intervention cannot be the overall solution to the unsustainable illegal trade of marine products. Motivations to get involved in such practices are location-specific and the systemic socioeconomic and cultural issues can vary also between communities in the same area. In the Trans-Fly social-ecological system, illegal trade of marine resources has different drivers, which should be tackled separately. Our findings emphasize the need to find innovative governance solutions to manage the stressed Trans-Fly social-ecological system, without which severe social, economic, and environmental repercussions could soon eventuate.

Responses to this article can be read online at: http://www.ecologyandsociety.org/issues/responses. php/9817

\section{Acknowledgments:}

SB thanks the people and ward members of the coastal villages in the South Fly for allowing her to work and live in their communities. The authors thank staff of the local NGO Bata CDF in Daru for their assistance in the field; without their assistance we would not have been able to conduct this study. We also thank the provincial and district fisheries officials who provided support to the study. For preliminary statistical analysis SB thanks Takahiro Shimada. Garrick Hitchcock and John Burton ( ANU) provided protocols for the multidimensional poverty index estimation. Tim Skewes (CSIRO) provided the map in Fig. 1. The authors thank Ingrid Van Putten (CSIRO) and two anonymous reviewers for their constructive comments. Funding for this research was provided by the Australian Fisheries Management Authority and the PNG National Fisheries Authority. The Authors acknowledge the Torres Strait Protected Zone Joint Authority, which recommended the project. Data collection, analysis, and dissemination was conducted under the CSIRO Social Science Human Research Ethics Committee ethical clearance 085-12.

\section{LITERATURE CITED}

Alkire, S., and M. E. Santos. 2010. Acute multidimensional poverty: a new index for developing countries. Oxford Poverty and Human Development Initiative Working Paper 38. University of Oxford, Oxford, UK. http://dx.doi.org/10.2139/ssrn.1815243

Allen, B., R. M. Bourke, and J. Gibson. 2005. Poor rural places in Papua New Guinea. Asia Pacific Viewpoint 46:201-217. http:// dx.doi.org/10.1111/j.1467-8373.2005.00274.x

Anderson, S. C., J. M. Flemming, R. Watson, and H. K. Lotze. 2011. Serial exploitation of global sea cucumber fisheries. Fish and Fisheries 12:317-339. http://dx.doi.org/10.1111/ j.1467-2979.2010.00397.X

Arvey, R. D., and M. A. Cavanaugh. 1995. Using surveys to assess the prevalence of sexual harassment: some methodological problems. Journal of Social Issues 51(1):39-52. http://dx.doi. org/10.1111/j.1540-4560.1995.tb01307.x

Asafu-Adjaye, J. 2000. Customary marine tenure systems and sustainable fisheries management in Papua New Guinea: the case of the western province. International Journal of Social Economics 27(7/8/9/10):917-926. http://dx.doi.org/10.1108/03068290010336856

Australian Fisheries Management Authority (AFMA). 2011. Strategic and export reassessment report: Torres Strait Beche-demer fishery. Report on behalf of the Torres Strait Protected Zone Joint Authority. AFMA, Canberra Australia. [online] URL: https://www.environment.gov.au/system/files/pages/0490a46d-fadf-4823bcaf-32424191c595/files/submission-april2011.pdf

Australian Fisheries Management Authority (AFMA). 2013. Annual Report: Torres Strait Beche-de-mer Fishery. Report on behalf of the Torres Strait Protected Zone Joint Authority. AFMA, Canberra Australia.

Barnett, J. 1998. Sensitive questions and response effects: an evaluation. Journal of Managerial Psychology 13(1/2):63-76. http://dx.doi.org/10.1108/02683949810369138

Berkes, F., T. P. Hughes, R. S. Steneck, J. A. Wilson, D. R. Bellwood, B. Crona, C. Folke, L. H. Gunderson, H. M. Leslie, J. Norberg, M. Nyström, P. Olsson, H. Österblom, M. Scheffer, and B. Worm. 2006. Globalization, roving bandits, and marine resources. Science 311(5767):1557-1558. http://dx.doi.org/10.1126/ science. 1122804

Busilacchi, S., G. R. Russ, A. J. Williams, S. G. Sutton, and G. A. Begg. 2013. The role of subsistence fishing in the hybrid economy of an indigenous community. Marine Policy 37:183-191. http:// dx.doi.org/10.1016/j.marpol.2012.04.017

Butler J. R. A., E. Bohensky, Y. Maru, S. Busilacchi, V. Chewings, and T. Skewes. 2012a. Synthesis and projections of human population and socio-economic drivers in Torres Strait and Western Province, PNG. National Environmental Research Program. Reef and Rainforest Research Centre Limited, Cairns, Australia. [online] URL: http://www.nerptropical.edu.au/sites/default/files/ publications/files/Project $\% 2011.1$ Torres $\% 20$ Strait $\% 20$ drivers $\% 20$ of $\%$ 20change milestone $\% 20$ June $\% 202012$-upload.pdf 
Butler, J. R. A., E. Bohensky, T. Skewes, Y. Maru, S. Busilacchi, W. Rochester, J. Katzfey, and R. M. Wise. 2015b. Drivers of change in the Torres Strait Region: status and trends. National Environmental Research Program. Reef and Rainforest Research Centre Limited, Cairns, Australia. [online] URL: http://www. nerptropical.edu.au/sites/default/files/publications/files/Drivers $\%$ 20of $\% 20$ change $\% 20$ in $\% 20$ the $\% 20$ Torres... $\% 20$ Butler $\% 20$ et $\% 20$ al $\%$ 202014a.pdf

Butler, J. R. A., S. Busilacchi, J. Posu, I. Liviko, P. Kokwaiye, S. C. Apte, and A. Steven. 2015a. South Fly District future development workshop report. Report prepared by CSIRO Oceans and Atmosphere, Brisbane, and the Papua New Guinea National Fisheries Authority, Port Moresby, Papua New Guinea. [online] URL: https://www.academia.edu/35395802/OCEANS AND ATMOSPHERE_South_Fly_District_Future_Development_Workshop Report

Butler, J. R. A., T. Skewes, D. Mitchell, M. Pontio, and T. Hills. 2014. Stakeholder perceptions of ecosystem service declines in Milne Bay, Papua New Guinea: Is human population a more critical driver than climate change? Marine Policy 46:1-13. http:// dx.doi.org/10.1016/j.marpol.2013.12.011

Butler, J. R. A., A. Tawake, T. Skewes, L. Tawake, and V. McGrath. 2012b. Integrating traditional ecological knowledge and fisheries management in the Torres Strait, Australia: the catalytic role of turtles and dugong as cultural keystone species. Ecology and Society 17(4):34. http://dx.doi.org/10.5751/ES-05165-170434

Catania, J. A., D. Binson, J. Canchola, L. M. Pollack, W. Hauck, and T. J. Coates. 1996. Effects of interviewer gender, interviewer choice, and item wording on responses to questions concerning sexual behavior. Public Opinion Quarterly 60:345-375. http://dx. doi.org/10.1086/297758

Cinner, J. 2005. Socioeconomic factors influencing customary marine tenure in the Indo-Pacific. Ecology and Society 10(1):36. http://dx.doi.org/10.5751/ES-01364-100136

Clarke, S. 2004. Understanding pressures on fishery resources through trade statistics: a pilot study of four products in the Chinese dried seafood market. Fish and Fisheries 5:53-74. http:// dx.doi.org/10.1111/j.1467-2960.2004.00137.x

Coad, L., K. Abernethy, A. Balmford, A. Manica, L. Airey, and E. J. Milner-Gulland. 2010. Distribution and use of income from bushmeat in a rural village, central Gabon. Conservation Biology 24(6):1510-1518. http://dx.doi.org/10.1111/j.1523-1739.2010.01525. $\underline{\mathrm{X}}$

de Jong, W. 2008. Transborder environmental and natural resource management. CIAS Discussion Paper No. 4. Centre for Integrated Area Studies, Kyoto, Japan. [online] URL: https://www. researchgate.net/profile/Darryn Mcevoy/publication/41057393 The role_of institutional_capacity in enabling_climate change adaptation the case of the Guadiana River Basin/

links/0046352ddaf550dc9c000000.pdf

Duffy, R., F. A. V. St John, B. Büscher, and D. Brockington. 2016. Toward a new understanding of the links between poverty and illegal wildlife hunting. Conservation Biology 30(1):14-22. http:// dx.doi.org/10.1111/cobi.12622

Enck, J. W., D. J. Decker, S. J. Riley, J. F. Organ, L. H. Carpenter, and W. F. Siemer. 2006. Integrating ecological and human dimensions in adaptive management of wildlife-related impacts. Wildlife Society Bulletin 34:698-705. http://dx.doi.org/10.2193/0091-7648 (2006)34[698:IEAHDI]2.0.CO;2

Fabinyi, M. 2012. Historical, cultural and social perspectives on luxury seafood consumption in China. Environmental Conservation 39(01):83-92. http://dx.doi.org/10.1017/S0376892911000609

Fabinyi, M., M. Pido, E. M. Ponce de Leon, M. A. De las Alas, J. Buenconsejo, A. Uyami-Bitara, B. Harani, and J. Caceres. 2014. Fisheries trade and social development in the PhilippineMalaysia Maritime Border Zone. Development Policy Review 32 (6):715-732. http://dx.doi.org/10.1111/dpr.12086

Foale, S., D. Adhuri, P. Aliño, E. H. Allison, N. Andrew, P. Cohen, L. Evans, M. Fabinyi, P. Fidelman, C. Gregory, N. Stacey, J. Tanzer, and N. Weeratunge. 2013. Food security and the Coral Triangle initiative. Marine Policy 38:174-183. http://dx.doi. org/10.1016/j.marpol.2012.05.033

Gavin, M. C., J. N. Solomon, and S. G. Blank. 2010. Measuring and monitoring illegal use of natural resources. Conservation Biology 24:89-100. http://dx.doi.org/10.1111/j.1523-1739.2009.01387. $\underline{\mathrm{X}}$

Gibson, J., and S. Rozelle. 2002. Poverty and access to infrastructure in Papua New Guinea. Working Paper No. 02-008. Department of Agriculture and Resource Economics, University of California Davis, USA. http://dx.doi.org/10.2139/ssrn.334140

Gribble, J. N., H. G. Miller, S. M. Rogers, and C. F. Turner. 1999. Interview mode and measurement of sexual behaviors: methodological issues. Journal of Sex Research 36(1):16-24. http://dx.doi.org/10.1080/00224499909551963

Hanson, L. W., B. J. Allen, R. M. Bourke, and T. J. McCarthy. 2001. Papua New Guinea rural development handbook. Land Management Group, Australian National University, Canberra, Australia.

Harrison, L. 1997. The validity of self-reported drug use in survey research: an overview and critique of research methods. NIDA Research Monographs 167:17-36. [online] URL: https://www. ncbi.nlm.nih.gov/pubmed/9243555

Horstmann, A. 2004. Incorporation and resistance: borderlands, transnational communities and social change in Southeast Asia. Transnational Communities Programme Working Paper WPTC-02-04. Institute of Social and Cultural Anthropology, Oxford University, Oxford, UK. [online] URL: http://www. transcomm.ox.ac.uk/working $\% 20$ papers/WPTC-02-04\%20Horstmann. pdf

Johannes, R. E., and J. W. MacFarlane. 1991. Traditional fishing in the Torres Strait Islands. CSIRO Division of Fisheries, Hobart, Tasmania.

Keane, A., J. P. G. Jones, G. Edwards-Jones, and E. J. MilnerGulland. 2008. The sleeping policeman: understanding issues of enforcement and compliance in conservation. Animal Conservation 11:75-82. http://dx.doi.org/10.1111/j.1469-1795.2008.00170. $\underline{\mathrm{x}}$

Kinch, J., M. James, E. Thomas, P. Lauhi, and R. Gabiobu. 2007. Socio-economic assessment of the Beche-de-Mer Fisheries in the Western, Central and Manus Provinces, Papua New Guinea. National Fisheries Authority, Port Moresby, Papua New Guinea. 
Kinch, J., S. Purcell, S. Uthicke, and K. Friedman. 2008. Papua New Guinea: a hotspot of sea cucumber fisheries in the Western Central Pacific. Pages 57-77 in V. Toral-Granda, A. Lovatelli and M. Vasconcellos, editors. Sea cucumbers. A global review of fisheries and trade. FAO Fisheries and Aquaculture Technical Paper. No. 516. FAO, Rome, Italy.[online] URL: http://www.fao. org/docrep/011/i0375e/i0375e00.htm

Kramer, D. B., G. Urquhart, and K. Schmitt. 2009. Globalization and the connection of remote communities: a review of household effects and their biodiversity implications. Ecological Economics 68(12):2897-2909. http://dx.doi.org/10.1016/j.ecolecon.2009.06.026

Lindsey P. A., S. S. Romanach, S. Matema, C. Matema, I. Mupamhadzi, and J. Muvengwi. 2011. Dynamics and underlying causes of illegal bushmeat trade in Zimbabwe. Oryx 45(01):84-95. http://dx.doi.org/10.1017/S0030605310001274

Lokuge, K., K. Salee, and A. Konstantinos. 2012. Tuberculosis control in the Torres Strait region: What's needed and why? Report following a public forum. Development Policy Centre Discussion Paper 22. Crawford School of Public Policy, The Australian National University, Canberra, Australia. [online] URL: https:// papers.ssrn.com/sol3/papers.cfm?abstract $\mathrm{id}=2126915$

Marquis, K. H., N. Duan, M. S. Marquis, J. M. Polich, J. E. Meshkoff, D. S. Schwarzbach, and C. Stasz. 1981. Response errors in sensitive topics surveys: executive summary. Rand Corporation, Santa Monica, California, USA. [online] URL: https://www. rand.org/content/dam/rand/pubs/reports/2006/R2710.2.pdf

Mateo-Tomas, P., P. P. Olea, I. S. Sanchez-Barbudo, and R. Mateo. 2012. Alleviating human-wildlife conflicts: identifying the causes and mapping the risk of illegal poisoning of wild fauna. Journal of Applied Ecology 49:376-385. http://dx.doi.org/10.1111/ j.1365-2664.2012.02119.x

Milner-Gulland, E. J. 2012. Interactions between human behaviour and ecological systems. Philosophical Transactions of the Royal Society of London. Series B: Biological Sciences 367:270-278. [online] URL: http://dx.doi.org/10.1098/rstb.2011.0175

Milner-Gulland, E. J., and E. L. Bennett. 2003. Wild meat: the bigger picture. Trends in Ecology \& Evolution 18(7):351-357. http://dx.doi.org/10.1016/S0169-5347(03)00123-X

National Fisheries Authority (NFA). 2004. The barramundi Fishery Management Plan. NFA, Port Moresby, Papua New Guinea.

National Statistical Office (NSO). 2010. Western Province: socioeconomic urban survey. NSO/PNG Sustainable Development Program Ltd., Port Moresby, Papua New Guinea. http://pngsdp. org/wp-content/uploads/2017/04/wp-socio-economic-urban.pdf

Nellemann, C., R. Henriksen, P. Raxter, N. Ash, and E. Mrema. 2014. The environmental crime crisis: threats to sustainable development from illegal exploitation and trade in wildlife and forest resources. A UNEP Rapid Response Assessment. United Nations Environment Programme, Nairobi, Kenya and GRID-Arendal, Arendal, Norway. https://www.cbd.int/financial/monterreytradetech/ unep-illegaltrade.pdf

O’Donnell, L. R. 2006. The Torres Strait: a case study analysis on multi-level governance. Dissertation. Griffith University,
Brisbane, Australia. https://www120.secure.griffith.edu.au/rch/ file/88cfcaec-c683-7122-4ac2-75ec0b82acee/1/02Whole.pdf

Pitcher, T. J., R. Watson, R. Forrest, H. Pór Valtýsson, and S. Guénette. 2002. Estimating illegal and unreported catches from marine ecosystems: a basis for change. Fish and Fisheries 3:317-339. http://dx.doi.org/10.1046/j.1467-2979.2002.00093.x

Roe, D. 2015. Conservation, crime and communities: case studies of efforts to engage local communities in tackling illegal wildlife trade. International Institute for Environment and Development, London, UK. http://pubs.iied.org/14648IIED/

Roe, D., F. Booker, M. Day, W. Zhou, S. Allebone-Webb, N. A. O. Hill, N. Kumpel, G. Petrokofsky, K. Redford, D. Russell, G. Shepherd, J. Wright, and T. C. H. Sunderland. 2015b. Are alternative livelihood projects effective at reducing local threats to specified elements of biodiversity and/or improving or maintaining the conservation status of those elements? A systematic review protocol. Environmental Evidence 4:22. http:// dx.doi.org/10.1186/s13750-015-0048-1

Roe, D., R. Cooney, H. Dublin, D. Challender, D. Biggs, D. Skinner, M. Abensperg-Traun, N. Ahler, R. Melisch, and M. Murphree. 2015a. Beyond enforcement: engaging communities in tackling wildlife crime. International Institute for Environment and Development, London, UK. [online] URL: http://pubs.iied. org/17293IIED/

Rosen, G. E., and K. F. Smith. 2010. Summarizing the evidence on the international trade in illegal wildlife. EcoHealth 7(1):24-32. http://dx.doi.org/10.1007/s10393-010-0317-y

Sadovy, Y. J., T. J. Donaldson, T. R. Graham, F. McGilvray, G. J. Muldoon, M. J. Phillips, M. A. Rimmer, A. Smith, and B. Yeeting. 2003. While stocks last: the live reef food fish trade. Asian Development Bank, Manila, Philippines. [online] URL: https:// www.adb.org/sites/default/files/publication/28455/live-reef-complete. pdf

Sanderson, E. W., J. Malanding, M. A. Levy, K. H. Redford, A. V. Wannebo, and G. Woolmer. 2002. The human footprint and the last of the wild. BioScience 52:891-904. http://dx.doi. org/10.1641/0006-3568(2002)052[0891:THFATL]2.0.CO;2

Schug, D. 1996. International maritime boundaries and indigenous people. The case of the Torres Strait. Marine Policy 20(3):209-222. http://dx.doi.org/10.1016/0308-597X(95)00046-9

Singer, E., D. R. Von Thurn, and E. R Miller. 1995. Confidentiality assurances and response: a quantitative review of the experimental literature. Public Opinion Quarterly 59:66-77. http://dx.doi.org/10.1086/269458

Stewart, D. W., and P. N. Shamdasani. 1990. Focus groups: theory and practice. Sage, Newbury Park, California, USA. [online] URL: http://www.upv.es/i.grup/repositorio/Stewart $\% 20$ Shamdasani $\%$ 201990\%20Focus\%20Groups.pdf

Tagliacozzo, E. 2001. Border permeability and the state in Southeast Asia: contraband and regional security. Contemporary Southeast Asia 23(2):254-74. http://www.jstor.org/stable/25798545

Twinamatsiko, M., J. Baker, M. Harrison, M. Shirkbhorshidi, R. Bitariho, M. Wieland, S. Asuma, E. J. Milner-Gulnard, P. Franks, and D. Roe. 2014. Linking conservation, equity and poverty 
alleviation: understanding profiles andmotivations of resource users and local perceptions of governance at Bwindi Impenetrable National Park, Uganda. International Institute for Environment and Development, London, UK. [online] URL: http://pubs.iied. org/pdfs/14630IIED.pdf

van Vliet, N. 2011. Livelihood alternatives for the unsustainable use of bushmeat. Report Prepared for the CBD Bushmeat Liaison Group. Technical Series No. 60. Secretariat of the Convention on Biological Diversity, Montréal, Québec, Canada. [online] URL: https://www.cbd.int/doc/publications/cbd-ts-60-en.pdf

Velasco, D. 2010. Navigating the Indonesian-Philippine border: the challenges of life in the borderzone. Kasarinlan: Philippine Journal of Third World Studies 25(1-2):95-118. [online] URL: http://journals.upd.edu.ph/index.php/kasarinlan/article/view/1999

Watson, D. 1989. The evolution of appropriate resourcemanagement systems. Pages 54-69 in F. Berkes, editor. Common property resources: ecology and community-based sustainable development. Belhaven Press, London, England.

Wicander, S., and L. Coad. 2015. Learning our lessons: a review of alternative livelihood projects in Central Africa. Environmental Change Institute, University of Oxford, Oxford, UK. http://dx. doi.org/10.2305/IUCN.CH.2015.01.en

World Bank. 2015. Staying the course. World Bank, Washington, D.C., USA. [online] URL: http://pubdocs.worldbank.org/ en/414911444005973491/pdf/EAP-Economic-Update-2015-10.pdf

Wright, J. H., N. A. O. Hill, D. Roe, J. M. Rowcliffe, N. F. Kümpel, M. Day, F. Booker, and E. J. Milner-Gulland. 2016. Reframing the concept of alternative livelihoods. Conservation Biology 30:7-13. http://dx.doi.org/10.1111/cobi.12607

Zhang, L., N. Hua, and S. Sun. 2008. Wildlife trade, consumption and conservation awareness in southwest China. Biodiversity and Conservation 17(6):1493-1516. http://dx.doi.org/10.1007/s10531-008-9358-8 
Appendix 1. Number of households surveyed in the PNG Treaty Villages and Daru, and their proportion of the total households.

\begin{tabular}{|c|c|c|}
\hline Question & Method & Data \\
\hline \multicolumn{3}{|c|}{ Involvement in illegal activities } \\
\hline \multirow[t]{6}{*}{ Village level } & Focus group discussions & $\begin{array}{l}\text { Issues with marine resources and fisheries (including illegal } \\
\text { trade) }\end{array}$ \\
\hline & & Role of marine resources for livelihoods \\
\hline & & Species harvested \\
\hline & Key informant interviews & $\begin{array}{l}\text { Issues with marine resources and fisheries (including illegal } \\
\text { trade) }\end{array}$ \\
\hline & & Role of marine resources for livelihoods \\
\hline & & Livelihood strategies in the communities \\
\hline \multirow[t]{3}{*}{ Household level } & Household questionnaire surveys & Sources of household income \\
\hline & & Species harvested \\
\hline & & Market outlets \\
\hline \multicolumn{3}{|c|}{ Drivers of engagement in illegal activities } \\
\hline & Household questionnaire surveys & Sources of household income \\
\hline & & Multidimensional Poverty Index indicators \\
\hline \multicolumn{3}{|c|}{ Intervention points and solutions } \\
\hline & Focus group discussions & $\begin{array}{l}\text { Systemic causes and impact of illegal trade on marine resource } \\
\text { and livelihoods }\end{array}$ \\
\hline & & $\begin{array}{l}\text { Intervention which could work in diverting communities from } \\
\text { illegal activities }\end{array}$ \\
\hline
\end{tabular}


Appendix 2. Survey methods and data collected to address the three research questions. 10

FGDs, $13 \mathrm{KI}$ interviews, and 1100 household questionnaires were conducted in the 14 Treaty villages and Daru.

\begin{tabular}{|l|l|l|l|l|}
\hline Village group & Village/Ward & Sample size & $\begin{array}{l}\text { Households in } \\
2012-2013^{\dagger}\end{array}$ & $\begin{array}{l}\text { Proportion } \\
\text { surveyed (\%) }\end{array}$ \\
\hline Western & Bula & 30 & 47 & 64 \\
\hline & Jarai & 30 & 44 & 68 \\
\hline & Mari & 38 & 62 & 61 \\
\hline & Tais & 47 & 67 & 70 \\
\hline Central & Buzi & 52 & 86 & 61 \\
\hline & Ber & 16 & 32 & 50 \\
\hline & Sigabaduru & 83 & 230 & 36 \\
\hline Eastern & Mabudauan & 125 & NA & NA \\
\hline & Old Mawatta & 36 & 48 & 75 \\
\hline & Ture ture & 41 & 73 & 56 \\
\hline & Kadawa & 77 & NA & NA \\
\hline & Katatai & 37 & NA & NA \\
\hline & Parama & 72 & NA & NA \\
\hline & Sui & 67 & 91 & 74 \\
\hline Daru & Traditional owners & 177 & 1800 & \\
\hline & $\begin{array}{l}\text { Fly River } \\
\text { immigrants }\end{array}$ & 147 & 1800 & \\
\hline & $\begin{array}{l}\text { Other areas } \\
\text { immigrants }\end{array}$ & 25 & 1800 & \\
\hline & Total Daru & 349 & 1800 & 19 \\
\hline
\end{tabular}

${ }^{\dagger}$ As reported by Village Recorders

* Not available 
Appendix 3. Marine products harvested and traded illegally from the South Fly, listed in descending order of value as reported by respondents in the FGDs. The international and domestic regulations breached by these activities are also reported.

\begin{tabular}{|c|c|c|c|}
\hline Product & $\begin{array}{l}\text { Torres Strait } \\
\text { Treaty } 1978\end{array}$ & $\begin{array}{l}\text { PNG-Indonesia special } \\
\text { arrangements } 1993\end{array}$ & Domestic or international regulations \\
\hline \multirow[t]{4}{*}{$\begin{array}{l}\text { Beche- } \\
\text { de-mer }\end{array}$} & $\begin{array}{l}\text { Article 16: } \\
\text { Capture in the } \\
\text { Torres Strait } \\
\text { Protected } \\
\text { Zone for } \\
\text { commercial } \\
\text { (i.e. non- } \\
\text { traditional) } \\
\text { purposes }\end{array}$ & $\begin{array}{l}\text { Article 11.1: } \\
\text { Commercial (i.e. non- } \\
\text { customary) cross-border } \\
\text { trade with Indonesian } \\
\text { buyers }\end{array}$ & $\begin{array}{l}\text { Australia: BDM management } \\
\text { arrangements }\end{array}$ \\
\hline & & & PNG: BDM management plan 2016 \\
\hline & & & $\begin{array}{l}\text { PNG: National Agriculture Quarantine } \\
\text { and Inspection Authority Act } 1997\end{array}$ \\
\hline & & & PNG: NFA export procedures \\
\hline \multirow[t]{2}{*}{ Shark fin } & & $\begin{array}{l}\text { Article 11.1: } \\
\text { Commercial (i.e. non- } \\
\text { customary) cross-border } \\
\text { trade with Indonesian } \\
\text { buyers }\end{array}$ & $\begin{array}{l}\text { PNG: National Agriculture Quarantine } \\
\text { and Inspection Authority Act } 1997\end{array}$ \\
\hline & & & PNG: NFA export procedures \\
\hline \multirow[t]{3}{*}{$\begin{array}{l}\text { Barramu } \\
\text { ndi and } \\
\text { jewfish } \\
\text { bladders }\end{array}$} & & $\begin{array}{l}\text { Article 11.1: } \\
\text { Commercial (i.e. non- } \\
\text { customary) cross-border } \\
\text { trade with Indonesian } \\
\text { buyers }\end{array}$ & $\begin{array}{l}\text { PNG: NFA Barramundi Management } \\
\text { Plan }\end{array}$ \\
\hline & & & $\begin{array}{l}\text { PNG: National Agriculture Quarantine } \\
\text { and Inspection Authority Act } 1997\end{array}$ \\
\hline & & & PNG: NFA export procedures \\
\hline \multirow[t]{3}{*}{$\begin{array}{l}\text { Barramu } \\
\text { ndi and } \\
\text { jewfish } \\
\text { meat }\end{array}$} & $\begin{array}{l}\text { Article 16: } \\
\text { Capture and } \\
\text { sale of } \\
\text { barramundi } \\
\text { and jewfish } \\
\text { meat in } \\
\text { Torres Strait } \\
\text { Protected } \\
\text { Zone for } \\
\text { commercial } \\
\text { (i.e. non- } \\
\text { traditional) } \\
\text { purposes }\end{array}$ & $\begin{array}{l}\text { Article 11.1: } \\
\text { Commercial (i.e. non- } \\
\text { customary) cross-border } \\
\text { trade with Indonesian } \\
\text { buyers }\end{array}$ & $\begin{array}{l}\text { PNG: NFA Barramundi Management } \\
\text { Plan }\end{array}$ \\
\hline & & & $\begin{array}{l}\text { PNG: National Agriculture Quarantine } \\
\text { and Inspection Authority Act } 1997\end{array}$ \\
\hline & & & PNG: NFA export procedures \\
\hline Crabs & $\begin{array}{l}\text { Article 16: } \\
\text { Capture and } \\
\text { sale of crabs } \\
\text { in Torres } \\
\text { Strait }\end{array}$ & $\begin{array}{l}\text { Article 11.1: } \\
\text { Commercial (i.e. non- } \\
\text { customary) cross-border } \\
\text { trade with Indonesian } \\
\text { buyers }\end{array}$ & $\begin{array}{l}\text { PNG: National Agriculture Quarantine } \\
\text { and Inspection Authority Act } 1997\end{array}$ \\
\hline
\end{tabular}




\begin{tabular}{|l|l|l|l|}
\hline & $\begin{array}{l}\text { Protected } \\
\text { Zone for } \\
\text { commercial } \\
\text { (i.e. non- } \\
\text { traditional) } \\
\text { purposes }\end{array}$ & & \\
\hline Shellfish & $\begin{array}{l}\text { Article 16: } \\
\text { Capture and } \\
\text { sale of crabs } \\
\text { in Torres } \\
\text { Strait } \\
\text { Protected } \\
\text { Zone for } \\
\text { commercial } \\
\text { (i.e. non- } \\
\text { traditional) } \\
\text { purposes }\end{array}$ & $\begin{array}{l}\text { Article 11.1: } \\
\text { Commercial (i.e. non- } \\
\text { customary) cross-border } \\
\text { trade with Indonesian } \\
\text { buyers }\end{array}$ & $\begin{array}{l}\text { PNG: National Agriculture Quarantine } \\
\text { and Inspection Authority Act } 1997\end{array}$ \\
\hline & & \\
\hline
\end{tabular}

